\title{
UNIVERSITYOF
}

FORWARD

THINKING

WESTMINSTER用

WestminsterResearch

http://www.westminster.ac.uk/westminsterresearch

\section{Religion and returns in Europe}

Salaber J.

NOTICE: this is the authors' version of a work that was accepted for publication in European Journal of Political Economy. Changes resulting from the publishing process, such as peer review, editing, corrections, structural formatting, and other quality control mechanisms may not be reflected in this document. Changes may have been made to this work since it was submitted for publication. A definitive version was subsequently published in European Journal of Political Economy, 32 149-160 0176-2680.

European Journal of Political Economy is available online at:

https://dx.doi.org/10.1016/j.ejpoleco.2013.07.002

(C) 2013. This manuscript version is made available under the CC-BY-NC-ND 4.0 license http://creativecommons.org/licenses/by-nc-nd/4.0/

The WestminsterResearch online digital archive at the University of Westminster aims to make the research output of the University available to a wider audience. Copyright and Moral Rights remain with the authors and/or copyright owners.

Whilst further distribution of specific materials from within this archive is forbidden, you may freely distribute the URL of WestminsterResearch: ((http://westminsterresearch.wmin.ac.uk/)).

In case of abuse or copyright appearing without permission e-mail repository@westminster.ac.uk 


\title{
Religion and Returns in Europe
}

Julie Salaber

\begin{abstract}
Drawing on social identity and social impact theory, this paper is the first to investigate the impact of religious preferences on share prices and expected returns at the country level. Using data from 12 European countries, our findings suggest that religion has a significant effect on the share price of companies whose activities are considered unethical, i.e., tobacco manufacturers and alcohol producers. The share price of these companies (called sin stocks) is depressed when they are located in a predominantly Protestant environment (relative to a Catholic environment). With investors in Protestant countries being more sin averse than in Catholic countries, they insist upon higher expected returns on sin stocks. Conversely, religious preferences do not have the same impact on the performance of other companies, e.g. socially responsible companies. Our results are robust to various methodologies and controlling for several firm-specific, industry-specific and country-specific characteristics.
\end{abstract}

Keywords: financial performance; religious preferences; sin stock premium; social identity; social responsibility

JEL Classifications: A13, G11, G12, Z12 


\section{Introduction}

Since the work of Weber (1905), it is recognized that religion affects economic attitudes and the activities of individuals, groups and societies. Authors usually distinguish between the macroeconomic impact of religion (e.g. on economic growth, international trade, government quality) and its microeconomic effect (on individual behaviours towards marriage, suicide, alcohol consumption, risk, etc.). At the micro level, recent research has linked individual religiosity to the level of participation in financial markets. Kumar et al. (2011) report that investors located in a Protestant environment are less likely to hold lottery-type stocks (with high firm-specific risk) than those located in a Catholic environment. They invoke social identity and social impact theory (Hogg and Abrams, 1988) to argue that 'the predominant local religion could influence local cultural values and norms and consequently affect the financial and economic decisions of individuals located in that region, even if they do not personally adhere to the dominant local faith' (Kumar et al., 2011). Similarly, Hood et al. (in press) and Kumar and Page (2011) show that investors belonging to different religious denominations will have different portfolio weights in the shares of companies with different social policies (e.g. favourable gay/lesbian policies) and companies involved in socially unproductive activities. For instance, they show that Catholic investors are more likely to own sin stocks than Protestant investors. Sin stocks are stocks of publicly-traded companies involved in the manufacturing of unethical products (e.g. alcohol and tobacco).

We combine this economic literature with finance literature in order to investigate, in an international context, the sin stock premium previously emphasized in US-based literature. Hong and Kacperczyk (2009) and Kumar and Page (2011) show that sin stocks in the US earn risk-adjusted abnormal returns compared to other stocks because of the existence of social norms. Even though Kumar and Page (2011) find that sin stock holdings are significantly different between Catholic and Protestant investors, they do not make any predictions about the impact of such difference on sin stock expected returns. ${ }^{1}$ By studying the sin stock premium in an international context, we are able to improve our understanding of the nature and source of such a premium. Outside the US, there is no evidence to date of a sin stock premium, or more generally on the impact of religion on aggregate financial decisions. We argue that, at the country level, the social norm hypothesis as an explanation for the sin stock premium is further heightened by the religious environment of investors. More specifically, the US is a

\footnotetext{
${ }^{1}$ The authors focus on sin stock holdings and portfolio performance of institutional investors. Moreover, they use the Catholic-to-Protestant ratio of each US County as a proxy for gambling preferences. As such, they include the Jewish population with Catholic residents and Latter-Day Saints with the Protestant population.
} 
predominantly Protestant country, a religious denomination known to have a strong tradition against alcohol and tobacco. Hence it is important to assess whether the sin stock premium would survive a more tolerant religious environment. A cross-country analysis of the sin stock premium allows for such macro-level analysis controlling for country-specific characteristics. In this paper, we examine the impact of religion on the share price of European companies. We argue that social identity and social impact theory also hold at the country level, i.e., the dominant religion of a country is likely to influence the financial decisions of investors in this country (even if they do not personally adhere to this religion), and thus significantly impact stock holdings and expected returns at the country level. First, religion still plays an important role in European societies. Indeed the revival of religion has been emphasized not only in the US but in many countries around the world, including European countries (Arruñada, 2010; Helble, 2007; Renneboog and Spaenjers, 2012; Smith et al., 1998). Moreover, the latest World Values Survey (responses collected between 2005 and 2007) clearly emphasizes that most people in Europe still consider themselves as being 'a religious person' (around 50\% of the population in France, Spain and the UK; around 60\% in Finland, the Netherlands and Switzerland; and more than $85 \%$ in Austria, Italy and Poland).

Second, there is evidence that investors have different portfolio preferences across different European countries. In particular, it is interesting to investigate the strategies employed by socially responsible (SR) investors across Europe, as Naber (2001) and Williams and Zinkin (2005) argue that the investment choice of SR investors is partly driven by their religious preferences. Some investment funds are explicitly based on religious and family values, such as the Timothy Plan funds and Amity funds in the UK. These funds employ 'specific moral screening criteria designed to avoid investing shareholders' money in any company that has a pattern of contributing to the cultural degradation of our society'. ${ }^{2}$ For instance, these religious funds systematically avoid investing in companies involved in the production of alcohol and tobacco. According to the European Sustainable Investment Forum (Eurosif), Sustainable and Responsible Investment in Protestant countries is dominated by the negative screening of controversial activities, i.e., excluding companies that violate certain principles or norms such as the United Nations' Global Compact, or companies that violate more personal and social values such as child labour or tobacco manufacturing (Eurosif, 2010). However, SR funds in Catholic countries primarily use positive screening consisting of a best-in-class approach, i.e.,

\footnotetext{
${ }^{2}$ Source: http://www.timothyplan.com/Funds/frame-OurFunds-overview.htm
} 
choosing top performing companies in a sector or category based on how they meet selected criteria (Eurosif, 2008).

Since the values and norms of the dominant religion are likely to influence financial behaviours at the country level, we investigate whether such aggregated behaviours have a significant impact on expected returns of European companies. Preliminary US-based evidence suggests that firms located in a more religious environment require a higher internal rate of return (Hilary and Hui, 2009). Thus we contribute to the literature on the economic impact of religion by studying the effect of religious preferences on stock holdings and expected returns. We show that religion significantly affects the risk-adjusted performance of companies at the country level. More specifically, we show that the sin stock premium is primarily driven by the religious environment of investors, i.e., we do not find any evidence of a sin stock premium in Catholic countries.

The rest of the paper is organised as follows. Section 2 discusses the theoretical and empirical motivations for our research question. Section 3 presents the data sources and methodology, and Section 4 reports the results for the impact of religious preferences on stock returns. Discussions and conclusions are provided in Section 5.

\section{The impact of religion on stock returns}

Fama and French (2007) provide a theoretical framework for studying how tastes for assets as consumption goods can affect asset prices. They develop market equilibrium in a world where some investors have tastes for assets that are not related to returns, i.e., they derive direct utility from their holdings of some assets, above and beyond the utility from general consumption that the payoffs on the assets provide. If these investors account for substantial invested wealth or take positions much different from those of the market portfolio, their tastes have a significant impact on expected returns. Overall, Fama and French find that expected returns are higher (lower) for assets that investors underweight (overweight). Similarly, Merton (1987) develops a model of segmented markets in which asset segmentation can have an important effect on asset prices. When many investors neglect a certain type of asset, this will create limited risk-sharing opportunities and thus significant downward pressure on prices. Merton finds that a decrease in the size of a company's investor base will increase investors' expected returns. Both models have similar implications in our particular framework. First, we consider the segmentation of European markets across countries, consistent with the empirical validation of Merton's model (Bianconi and Tan, 2010; King and Segal, 2008) as well as empirical evidence of home bias 
(Faruqee et al., 2004; Tesar and Werner, 1995). The home bias puzzle is consistent with Fama and French (2007) model as well as with the familiarity bias (Cao et al., 2011; Grinblatt and Keloharju, 2001). We thus assume that most agents consume and invest in their own country and expected stock returns can be different across countries, as risk premiums depend primarily on country-specific factors.

Second, we consider the segmentation of markets across stocks, in particular the segmentation of sin stocks. Because of the unethical nature of their products (and the potentially harmful effects of their consumption on health), sin stocks are negatively screened, not only by religious investors but by many socially responsible investors (Statman and Glushkov, 2009). Indeed, a large number of investors and fund managers avoid sin companies while integrating social screening within their investment decisions, and Hong and Kacperczyk (2009) argue that the market is segmented against sin stocks because of these non-pecuniary preferences. They suggest that the number of US investors neglecting sin companies is large enough to create limited risk-sharing opportunities and thus significant downward pressure on sin stock prices. They identify these investors as socially responsible investors subject to social norms and public scrutiny, e.g. pension funds, banks, insurance companies, religious organizations. Similarly, Fama and French (2007) argue that socially responsible investing is an extreme form of tastes for assets as consumption goods. These arguments are supported by Kim and Venkatachalam (2011) and Naber (2001) who show that sin stocks exhibit higher expected returns than other stocks. Although this literature shows that the non-financial preferences of investors (i.e., avoiding sin stocks because of social norms) have a direct impact on the share price of these companies, it is all US-based and does not take into account the possible difference in sin aversion across religious denominations.

We define sin aversion as the reluctance of an individual (consumer or investor) to choose sin products/companies over non-sin alternatives. Considering an investor who faces two types of stocks (sin stocks and non-sin stocks), each with a similar risk-return profile, a sin averse investor would prefer non-sin stocks over sin stocks. In Christian denominations, alcohol and tobacco are not considered as religious sins but they are considered differently by Catholic and Protestant populations. In the US, Protestants stand more rigorously against alcohol consumption (Johnson and Meier, 1990) and regulation (Satterthwaite, 2005) than Catholics. And this opposition is not limited to the US. Many Protestant countries view alcohol consumption as 'inevitably destructive' (Fagan and Butler, 2011) and a 'dangerous stimulant to aggressive or violent behaviour' (Levine, 1992). However, drinking in moderation has been 
accepted in the Catholic Church and only alcohol abuse is condemned. ${ }^{3}$ Regarding tobacco consumption, Protestants around the world have a strong tradition against tobacco, which Catholics do not have (WHO, 1999). Thus we argue that Protestants are more sin averse than Catholics, or in other words, that the products/activities considered as sinful by Catholic populations represent a subset of the products/activities considered as sinful by Protestant populations.

Applying the theoretical frameworks of Fama and French (2007) and Merton (1987) to our particular setting, we question whether investors located in Protestant countries require a higher return on sin stocks than on other stocks, consistent with the social norm hypothesis. If a significant number of investors residing in Protestant countries exhibit sin aversion when investing on financial markets, i.e., have tastes for assets as consumption goods, the investor base of sin companies is significantly reduced, pushing down the price of sin stocks and increasing their expected returns. On the one hand, a large number of investors are unwilling to invest in sin stocks and significantly underweight them in their portfolio. This neglect effect implies that the price of sin stocks will be depressed relative to their fundamental values because of limited risk sharing. On the other hand, some investors still willing to arbitrage these undervalued stocks will expect a higher return to compensate for this limited risk sharing. Fama and French (2007) argue that the offsetting actions by arbitrageurs do not suffice to cause the price effects of tastes to disappear over time. As a result investors residing in Protestant countries should require higher expected returns on sin stocks compared to other stocks. It is worth noting that, the US being predominantly Protestant, the sin stock premium found on US stock markets is consistent with our argument.

However we argue that sin stocks in Catholic countries should not earn the same abnormal return as investors in these countries do not exhibit the same sin aversion. Indeed, Catholicdominated populations do not consider alcohol and tobacco as sinful as Protestant-dominated populations do, and investors in Catholic countries do not extensively shun sin stocks from their portfolio. In other words, social norms against investing in sin stocks are weaker in Catholic countries than in Protestant countries.

Finally, we expect the aggregate impact of religion to be significant only for companies that are significantly underweighted by a large number of investors. For instance, we do not expect religion to have an impact on the price of sustainable stocks which are usually favoured by socially responsible investors. Indeed there is no reason to believe that social impact theory

\footnotetext{
${ }^{3}$ Dolentium Hominum, 19, VII, 1992; available at: http://archive.catholic.com/thisrock/1992/9203chap.asp
} 
should apply to investment decisions around good companies. This idea is consistent with the international literature investigating the performance of socially responsible portfolios and funds relative to conventional investments. Most studies do not find any significant difference of risk-adjusted returns between socially responsible and traditional funds (Cortez et al., 2009), which is consistent with Hudson's (2005) argument that the trading activity of ethical investors fails to affect share prices.

Overall, because of social impact, market segmentation and tastes for assets as consumption goods, we expect religious beliefs to significantly impact the share price of sin companies at the country level, i.e., sin stocks should earn a risk-adjusted premium in Protestant countries but not in Catholic countries. Thus we are interested in testing two main hypotheses:

H1: In Protestant countries, sin stocks significantly outperform other stocks.

H2: Sin stocks in Protestant countries significantly outperform sin stocks in Catholic countries.

In order to test these hypotheses, we compare the risk-adjusted performance of sin stocks in Protestant countries with two control groups of stocks: $i$ ) sin stocks in Catholic countries, and ii) sustainable stocks in Protestant countries.

\section{Data and empirical method}

This study focuses on the impact of religious preferences of investors on expected stock returns in a sample of 12 European countries over the period 1981-2006. We believe the European market is the best setting for our analysis as all European countries have a majority of Christian populations, although still showing cross-country differences in terms of dominant religious faiths. Moreover, Europeans as a whole have the highest alcohol consumption rate and are the largest producers of alcohol (WHO, 2004). The countries under study are Austria, Belgium, Denmark, Finland, France, the Republic of Ireland, Italy, Poland, Portugal, Spain, Sweden and the United Kingdom. Several European countries are excluded from the analysis for two main reasons. First, some countries do not have a clear majority of either Protestants or Catholics. This is the case of Germany where both denominations represent a large proportion of the population, and Greece which is primarily Orthodox. ${ }^{4}$ Second, we discarded countries where no (or only one) sin stock is traded. This includes Hungary, Luxembourg, the Netherlands, Norway and Switzerland. Our sample consists of two main components: country-level religion and macro data and firm-level financial data.

\footnotetext{
${ }^{4}$ As a robustness check, we also run the analysis including Germany as a Protestant country and findings remain qualitatively similar. See Section 4.3 for details.
} 


\subsection{Religion and other country-level data}

According to social impact theory, we can use country-level data on religion to proxy for aggregate behaviours towards sin stocks. Indeed the dominant religion of a country is likely to influence economic and financial decisions of investors in this country, even if they do not personally adhere to this religion. Following Stulz and Williamson (2003), the primary religion is defined as the one practiced by the largest fraction of the population of a country. The main data on religious denominations come from the 2000 CIA World Factbook and give the dominant religions in each country with the proportion of the population affiliated to each major religion. Table 1 shows the primary religion for each country, as well as the distribution of major denominations per country. ${ }^{5}$ All European countries in the sample are Christian, distributed between Catholic denomination - Austria, Belgium, France, the Republic of Ireland, Italy, Poland, Portugal, and Spain - and Protestant denomination - Denmark, Finland, Sweden, and the United Kingdom.

In order to rule out the impact of other country-level characteristics, we collect several macro variables to control for cross-country differences in terms of economic, legal and cultural environments. As measures of economic environment, we use four variables motivated by previous literature (Coates et al., 2010; Döpke and Pierdzioch, 2006; Feld and Voigt, 2003; McCleary and Barro, 2006): the GDP, the interest rate spread (difference between long-term and short-term interest rates), the inflation rate calculated on the EU Harmonized Index of Consumer Prices (HICP), and the openness to trade (sum of exports and imports in percentage of GDP). Data on annual real per capita GDP, monthly interest rates and HICP come from DataStream. ${ }^{6}$ Data on annual openness to trade come from the Penn World Table version 7.1 (Heston, Summers and Aten 2012). In order to control for the legal environment, we use the rule of law index from La Porta et al. (1997). Finally, to measure the cultural environment of each country, we select the IDV and UAI dimensions of Hofstede (1980)'s cultural index as we believe they are particularly relevant here. The individualism component (IDV) assesses the level of individualism or collectivism in the society, which allows us to control for the level of social identity and social impact. The uncertainty avoidance component (UAI) measures the degree to which the members of a society feel (un)comfortable with uncertainty and ambiguity, which is a good proxy for the familiarity bias. Both dimensions are collected from Hofstede's website.

\footnotetext{
${ }^{5}$ Many other sources validate these figures. See for instance www.adherents.com, www.thearda.com, and www.worldchristiandatabase.org.

${ }^{6}$ These variables are available at different times for each country, typically from the mid-1990s.
} 
Table 1

Dominant religion in each European country.

\begin{tabular}{|c|c|c|c|}
\hline Country & Dominant religion & Percent Catholic & Percent Protestant \\
\hline Austria & Catholic & 85 & 6 \\
\hline Belgium & Catholic & 75 & - \\
\hline Denmark & Protestant & - & 95 \\
\hline Finland & Protestant & - & 90 \\
\hline France & Catholic & 81 & 2 \\
\hline Rep. Ireland & Catholic & 93 & 3 \\
\hline Italy & Catholic & 98 & - \\
\hline Poland & Catholic & 95 & - \\
\hline Portugal & Catholic & 97 & 1 \\
\hline Spain & Catholic & 98 & - \\
\hline Sweden & Protestant & 2 & 94 \\
\hline United Kingdom ${ }^{\mathrm{a}}$ & Protestant & 16 & 43 \\
\hline
\end{tabular}

${ }^{a}$ There is only one stock exchange (London Stock Exchange) for all companies listed in the UK, so we have to consider a single dominant religion for the UK. Protestantism is a natural choice as England, Scotland and Wales are primarily Protestant (only Northern Ireland is equally represented by Protestant and Catholic populations).

\subsection{Financial data}

Monthly financial data on the return index ${ }^{7}$, market capitalization, ratio price-to-book value and exchange rates are downloaded from Thomson DataStream from December 1980 to December 2006. In order to mitigate any currency effects, the analysis is based on euro returns. Onemonth interest rates are used to proxy for the risk-free rate and are collected from OECD Statistics. See Appendix for details on preliminary data cleaning and the construction of market portfolios. Sin stocks are selected according to the DataStream classification into 'brewers', 'distillers \& vintners' and 'tobacco'. Over the entire period, there are 66 sin stocks, distributed as follows: 20 stocks belong to the brewers sector (e.g. Carlsberg and Inbev), 39 stocks are classified in distillers and vintners (e.g. Campari, Taittinger and Pernod-Ricard), and 7 stocks belong to the tobacco sector (e.g. Altadis and BAT). These low numbers are due to the fact that many sin companies are privately held. The list of control stocks includes companies that are considered as socially responsible. First we consider the constituent list of the Stoxx Europe Sustainability Index for inclusion in our portfolio. From this list we discard all countries not represented in our sample, as well as all financial firms (constrained by strict regulation).

\footnotetext{
${ }^{7}$ Stock prices are available at the end of each month, but information about dividends is limited to the dividend yield, only allowing calculation of annual returns. Since we need to calculate monthly returns, we retrieve an index created by DataStream which takes into account the dividends payment. The return index for any equity shows its theoretical growth in value, assuming that dividends are reinvested.
} 
Second we augment the portfolio using the Global 100 list of the most sustainable corporations in the world (from which 34 are located in Europe). The number of sustainable stocks in the sample is 59, including companies such as Centrica, Marks \& Spencer, Danone and Vivendi. Both lists of sin stocks and sustainable stocks are available from the author. For our analysis, we construct four portfolios: two portfolios of sin stocks (listed either in Catholic or Protestant countries) and two portfolios of sustainable stocks (listed either in Catholic or Protestant countries). All four portfolios are value-weighted every month and mutually exclusive. Descriptive statistics for each portfolio are presented in Table 2. For each group of countries, this table indicates the number of companies in each portfolio, the average firm size and price-to-book ratio (PTB) in December 1985, 1995 and 2005. In the early years of the sample not all stocks were listed, thereby decreasing the number of stocks in the analysis. In December 1985, there are only 11 sin stocks and 27 sustainable stocks in the sample, while these numbers reach 52 and 59 (respectively) in December 2005. The sin and sustainable portfolios do not have the same characteristics in every country, and on average sustainable stocks are larger than sin stocks in terms of market capitalization.

As robust statistics, we find that Catholic countries have more sin stocks (publicly listed) than Protestant countries. From DataStream, we computed the proportion of sin stocks in each country as the number of tobacco and alcohol stocks divided by the total number of quoted stocks. Although the fraction of sin stocks is very small in all countries (the highest being $5.2 \%$ in Spain), the percentage is three times higher in Catholic countries (average of 2.7\%) than in Protestant countries (average of $0.9 \%$ ).

\subsection{Methodology}

In order to compare the performance of sin stocks in Protestant countries with our two control groups (sin stocks in Catholic countries and sustainable stocks in Protestant countries), we use several measures of risk-adjusted performance and expect to find a significant abnormal return relative to both control groups. First, we conduct a mean-variance analysis which requires comparing stocks or portfolios simply based on their mean returns and variance of returns (Markowitz, 1952). In a mean-variance framework, investors would choose stocks with the highest average return (for a given level of risk) or stocks with the lowest risk (for a given level of return). We thus compute the average return and standard deviation of returns for each of our four portfolios. 


\section{Table 2}

Firm statistics of each portfolio per religious denomination and for selected years.

\begin{tabular}{|c|c|c|c|c|c|c|c|}
\hline & \multirow[b]{2}{*}{ year } & \multicolumn{2}{|c|}{ Number of firms } & \multicolumn{2}{|c|}{ Average firm size } & \multicolumn{2}{|c|}{ Average firm РTB } \\
\hline & & Sin & Sustainable & Sin & Sustainable & Sin & Sustainable \\
\hline \multirow{3}{*}{$\begin{array}{l}\text { Catholic } \\
\text { countries }\end{array}$} & 1985 & 5 & 17 & 302 & 1,100 & 1.33 & 1.71 \\
\hline & 1995 & 24 & 27 & 264 & 5,613 & 1.23 & 1.84 \\
\hline & 2005 & 40 & 36 & 1,436 & 20,915 & 3.97 & 2.80 \\
\hline \multirow{3}{*}{$\begin{array}{l}\text { Protestant } \\
\text { countries }\end{array}$} & 1985 & 6 & 10 & 2,053 & 4,050 & 1.95 & 2.51 \\
\hline & 1995 & 8 & 17 & 5,489 & 7,309 & 2.00 & 4.10 \\
\hline & 2005 & 12 & 23 & 11,333 & 21,426 & 8.77 & 3.93 \\
\hline
\end{tabular}

Notes: The average size is the mean market capitalization (price times shares outstanding) and is given in millions of euro. Catholic countries are Austria, Belgium, France, Republic of Ireland, Italy, Poland, Portugal and Spain; Protestant countries include Denmark, Finland, Sweden and the United Kingdom.

We also compute the Sharpe ratio (Sharpe, 1966), also called reward-to-variability ratio which measures the excess return of each portfolio (return in excess of the risk-free rate) per unit of risk (standard deviation of returns). Therefore, we expect sin stocks in Protestant countries to exhibit a higher Sharpe ratio relative to both control groups, offering a higher premium per unit of risk.

The second step in our performance analysis is to control for market risk. We thus calculate the excess monthly return net of the risk-free rate for our four portfolios and we estimate the Capital Asset Pricing Model (CAPM) of Sharpe (1964). The abnormal return on any portfolio is given by the intercept (alpha) of the CAPM model of the form:

$$
R_{p, t}-R_{f, t}^{g}=\alpha_{p}+\beta_{p}\left(R_{m, t}^{g}-R_{f, t}^{g}\right)+\varepsilon_{p, t},
$$

where $R_{p}$ is the return of the portfolio, $R_{f}^{g}$ is the global risk-free rate and $R_{m}^{g}$ represents the return on a value-weighted global market portfolio (see Appendix for details). In order to compare expected returns on sin stocks and sustainable stocks across different religious environments, we estimate this model separately for Catholic and Protestant countries, and test for the difference in alpha coefficients. As we expect sin stocks to earn a risk-adjusted premium in Protestant countries but not in Catholic countries, the alpha on the sin portfolio should be significantly higher in Protestant countries than in Catholic countries. Moreover, we expect sin stocks to exhibit a significantly higher alpha than sustainable stocks in Protestant countries. 
In addition to the market beta, other factors have been shown to significantly impact stock returns: the firm's size, its price-to-book ratio and its past returns. These factors correspond to the size effect (small capitalizations outperform large capitalizations) and value effect (value stocks outperform growth stocks) of Fama and French (1993), as well as the momentum effect of Jegadeesh and Titman (1995). We thus run the same performance analysis using the fourfactor model below:

$$
R_{p, t}-R_{f, t}^{g}=\alpha_{p}+\beta_{p}\left(R_{m, t}^{g}-R_{f, t}^{g}\right)+s_{p} S M B_{t}+h_{p} H M L_{t}+m_{p} M O M_{t}+\varepsilon_{p, t},
$$

where $S M B$ is the return on a small-minus-big portfolio, $H M L$ is the return on a high-minus-low book-to-market portfolio and $M O M$ is the return difference between past winners and past losers.

For our last measure of risk-adjusted performance, we compare sin stocks to all other stocks in our sample (not only sustainable stocks), i.e., we analyse a total number of 3,614 stocks over 12 countries (see Appendix for details). Thus we run cross-sectional regressions using individual stock returns and controlling for firm-specific, industry-specific and country-specific characteristics. Firm-level characteristics are the same as those introduced in the time-series analysis (market beta, firm's size, price-to-book ratio and past returns). We control for industry fixed effects by including a dummy variable where the industry is defined at a broader level than the sin industries (alcohol and tobacco). Country-level characteristics include the economic, legal and cultural variables defined in section 3.1 above. Moreover, in order to control for unobserved country characteristics in our analysis, we include country fixed effects as dummy variables for each country in our sample.

For this cross-sectional analysis, we use the methodology of Fama and MacBeth (1973) which follows three steps. First, we estimate individual market betas for each stock in the sample, using the following time-series equation:

$$
R E T_{i t}-R_{f t}^{n}=\alpha_{i}+\beta_{i}\left(R_{m t}^{n}-R_{f t}^{n}\right)+\varepsilon_{i t}
$$

where $R E T_{i}$ is the return of each individual stock, $R_{f}^{n}$ is the national risk-free rate and $R_{m}^{n}$ represents the return on the value-weighted national market portfolio. Second, we estimate the different risk premiums by a cross-sectional regression on the estimated betas $\bar{\beta}_{i}$ and on the various control variables (lagged for monthly data). For each month $t$, we run the following regression: 


$$
\begin{aligned}
& R E T_{i t}-R_{f t}^{n}=a_{t}+b_{0 t} \operatorname{DSIN}_{i}+b_{1 t} D_{R E L_{i}}+b_{2 t} \operatorname{DSIN}_{i} * D R E L_{i} \\
& +b_{3 t} \bar{\beta}_{i t-1}+b_{4 t} R E T_{i t-1}+b_{5 t} L O G M V_{i t-1}+b_{6 t} L O G P B_{i t-1}+b_{7 t} I N D_{i t} \\
& +b_{8 t} \text { LOGGDP }_{i t}+b_{9 t} \text { SPREAD }_{i t-1}+b_{10 t} \text { INFL }_{i t-1}+b_{11 t} \text { OPEN }_{i t} \\
& +b_{12 t} L A W_{i}+b_{13 t} I D V_{i}+b_{14 t} U A I_{i}+\mathbf{b}_{t} \mathbf{C}+\eta_{i t}
\end{aligned}
$$

$D S I N$ and DREL are dummy variables accounting for sin stocks and religion. DSIN equals one if the stock is a sin stock and zero otherwise. DREL equals one if the stock is listed in a Protestant country and zero otherwise. The term $D S I N * D R E L$ represents the interaction between both dummy variables. Since sin stocks should not earn a premium in all countries, we expect $b_{0}$ to be insignificantly different from zero. Similarly, religion should not impact all stocks, thus we do not expect $b_{1}$ to be significant either. However we expect $b_{2}$ to be positive and statistically significant, meaning that religion should affect only sin stocks or in other words, sin stocks should outperform other stocks only in Protestant countries. The other variables in the model are control variables accounting for firm-specific, industry-specific and country-specific characteristics. $\bar{\beta}_{i}$ is the firm $i$ 's beta estimated from equation (3). $R E T_{i t-1}$ is the return of stock $i$ for the previous month. $L O G M V_{i t-1}$ is the natural logarithm of firm $i$ 's market value (price times shares outstanding) at the end of month $t-1 . L O G P B_{i t-1}$ is the natural logarithm of firm $i$ 's market value divided by its book value at the end of month $t-1 . I N D_{i t}$ is a dummy variable equal to one if the stock belongs to the DataStream supersector "consumer goods' or 'consumer services', zero otherwise. LOGGDP ${ }_{i t}$ is the natural logarithm of the country's real per capita GDP for the year including $t$. SPREAD $D_{i t-l}$ is the difference between the 10 -year government bond yield and the 1-month interbank rate for the previous month. $I N F L_{i t-1}$ is the country's previous month inflation rate. $O P E N_{i t}$ is the country's index of openness to trade for the year including $t . L A W_{i}, I D V_{i}$ and $U A I_{i}$ are the country's indices for rule of law, individualism and uncertainty avoidance. $\mathbf{C}$ is a matrix-vector including a dummy variable for each country in our sample. Finally, we compute and report the time-series average of each coefficient.

\section{Empirical results}

\subsection{Mean-variance and time-series portfolio analysis}

The mean-variance analysis requires comparing sin stocks and sustainable stocks based on their mean returns and variance of returns, as well as their Sharpe ratios. Table 3 gives the mean returns and standard deviation of returns for sin stocks and sustainable stocks across Catholic 


\section{Table 3}

Return statistics, Sharpe ratios and time-series alphas of sin stocks and sustainable stocks in Catholic and Protestant countries.

\begin{tabular}{|c|c|c|c|c|c|c|c|}
\hline & \multicolumn{7}{|c|}{ Catholic countries } \\
\hline & Mean & Std dev & Min & Max & $\begin{array}{l}\text { Sharpe } \\
\text { ratio }\end{array}$ & $\begin{array}{l}\text { CAPM } \\
\text { alpha }\end{array}$ & $\begin{array}{l}\text { 4-factor } \\
\text { alpha }\end{array}$ \\
\hline Sin stocks & $1.46 \%$ & $5.39 \%$ & $-36.2 \%$ & $17.1 \%$ & 0.150 & $0.0047 *$ & 0.0003 \\
\hline \multirow[t]{3}{*}{ Sustainable stocks } & $1.59 \%$ & $5.20 \%$ & $-22.3 \%$ & $22.0 \%$ & 0.180 & $0.0036^{* *}$ & 0.0007 \\
\hline & \multicolumn{7}{|c|}{ Protestant countries } \\
\hline & Mean & Std dev & Min & Max & $\begin{array}{l}\text { Sharpe } \\
\text { ratio }\end{array}$ & $\begin{array}{l}\text { CAPM } \\
\text { alpha }\end{array}$ & $\begin{array}{l}\text { 4-factor } \\
\text { alpha }\end{array}$ \\
\hline Sin stocks & $1.71 \%$ & $5.79 \%$ & $-31.3 \%$ & $25.5 \%$ & 0.193 & $0.0063 * *$ & 0.0013 \\
\hline Sustainable stocks & $1.37 \%$ & $6.12 \%$ & $-23.2 \%$ & $19.3 \%$ & 0.133 & -0.0001 & 0.0048 \\
\hline
\end{tabular}

Notes: The Sharpe ratios are based on the Euro risk-free rate.

and Protestant countries. The table also reports the minimum and maximum returns over the sample period (1981-2006). From this table, it is clear that investors in Protestant countries would prefer sin stocks over sustainable stocks because of higher mean returns $(+0.34 \%$ per month or $4 \%$ per year on average) associated with lower risk. Thus the sin portfolio outperforms the sustainable portfolio (higher risk-adjusted return) and the Sharpe ratios confirm this result: the reward-to-variability ratio is 0.19 for sin stocks compared to 0.13 for sustainable stocks. These figures are consistent with our first hypothesis, i.e., sin stocks earn a risk-adjusted premium over sustainable stocks in Protestant countries. Our second hypothesis is also validated by the Sharpe ratio analysis, i.e., sin stocks in Protestant countries (Sharpe ratio of 0.19) outperform sin stocks in Catholic countries (Sharpe ratio of 0.15).

The last part of Table 3 shows the alpha coefficient estimates for the sin and sustainable portfolios from models (1) and (2) for both Catholic and Protestant countries. Regarding H1, sin stocks outperform sustainable stocks in Protestant countries only in the CAPM specification. The average risk-adjusted return on sin stocks is significantly positive and represents an abnormal profit of $0.63 \%$ per month (or $7.8 \%$ per year), which is significantly higher than the alpha for the sustainable portfolio ( $\mathrm{t}$-statistic for the difference in alphas $=2.10$ ). However, these abnormal returns disappear when controlling for additional risk factors ( $\mathrm{t}-$ statistic for the difference in four-factor alphas $=0.74$ ). Regarding H2, sin stocks in Protestant countries outperform sin stocks in Catholic countries, and this result holds both for the CAPM and the 4-factor model. Protestant investors seem to require a higher premium on sin stocks 
relative to Catholics investors (nearly $2 \%$ per year). However, these differences in alphas are statistically insignificant as the t-statistics report: 0.42 for the CAPM and 0.16 for the fourfactor model.

Overall, Table 3 provides support for our hypotheses. We find evidence that sin stocks earn different risk-adjusted returns in different religious environments. However the analysis so far is preliminary and we will now conduct a more thorough investigation into the determinants of these abnormal returns.

\subsection{Cross-sectional analysis on individual stocks}

Table 4 reports the mean coefficients (and t-statistics) from the Fama-MacBeth procedure. The advantage of this cross-sectional analysis is threefold. First, it includes all stocks traded on European markets (not just sin stocks and sustainable stocks), which represents 3,614 stocks in our sample. Second, each individual stock return can be assessed relative to its national riskfree rate and national market return, instead of a global risk-free rate and a global market portfolio. Third, in addition to firm-specific characteristics, we are able to control for countryspecific and industry-specific characteristics. Each coefficient in Table 4 represents the timeseries average of coefficients from equation (4).

Models (2), (4) and (6) include country dummies (not reported for brevity). These dummy variables are overall not significant. Among the other control variables, firm-specific characteristics typically have a significant impact on returns. The beta coefficients are positive, although not highly significant, and the other coefficients are significantly negative. These findings are consistent with previous literature on mean reversion (Jegadeesh and Titman, 1995), and on the size and value effects (Fama and French, 1993). The industry dummy does not help explain individual stock returns, and country-level variables do not typically impact returns either. The economic impact and statistical significance of country-level characteristics depends whether country dummies are included or not in the regression. The first specification (columns (1) and (2)) excludes the interaction term DSIN*DREL as well as the country-level variables (only available from 1995). The coefficients of interest are $b_{0}$ and $b_{1}$ which measure whether $\sin (D S I N)$ or religious preferences (DREL) have an impact on stock returns. These coefficients are statistically and economically insignificant, except DREL in model (2) which is significant at the $10 \%$ level. First, sin stocks as a whole (in all countries) do not earn any abnormal return relative to other stocks, which is in opposition with previous evidence on the outperformance of sin stocks in the US market (Kim and Venkatachalam, 2011). 
Table 4

Cross-sectional estimates of equation (4) using Fama-MacBeth procedure.

\begin{tabular}{|c|c|c|c|c|c|c|}
\hline & $(1)$ & (2) & (3) & (4) & (5) & (6) \\
\hline \multirow[t]{2}{*}{ DSIN } & 0.0006 & 0.0013 & -0.0021 & -0.0015 & -0.0002 & 0.0000 \\
\hline & $(0.42)$ & $(0.97)$ & $(-1.03)$ & $(-0.83)$ & $(-0.12)$ & $(-0.01)$ \\
\hline \multirow[t]{2}{*}{$D R E L$} & 0.0014 & $0.0076 *$ & 0.0013 & $0.0072 *$ & 0.0033 & -0.0158 \\
\hline & $(0.61)$ & $(1.83)$ & $(0.56)$ & $(1.75)$ & $(0.41)$ & $(-0.77)$ \\
\hline \multirow[t]{2}{*}{$D S I N * D R E L$} & & & $0.0061 * *$ & $0.0067 * * *$ & $0.0071 * *$ & $0.0068 * *$ \\
\hline & & & $(2.19)$ & $(2.52)$ & $(2.03)$ & $(1.97)$ \\
\hline \multirow[t]{2}{*}{$\beta$} & $0.0039 *$ & $0.0044 * *$ & $0.0039 *$ & $0.0043 * *$ & 0.0022 & 0.0018 \\
\hline & $(1.82)$ & $(2.03)$ & $(1.85)$ & $(2.02)$ & $(0.77)$ & $(0.63)$ \\
\hline \multirow[t]{2}{*}{ RET } & $-0.0376 * * *$ & $-0.0438 * * *$ & $-0.0376 * * *$ & $-0.0438 * * *$ & $-0.0412 * * *$ & $-0.0423 * * *$ \\
\hline & $(-7.34)$ & $(-8.53)$ & $(-7.35)$ & $(-8.56)$ & $(-5.87)$ & $(-5.99)$ \\
\hline \multirow[t]{2}{*}{$L O G M V$} & $-0.0010 * * *$ & $-0.0012 * * *$ & $-0.0010 * * *$ & $-0.0012 * * *$ & -0.0005 & -0.0005 \\
\hline & $(-2.37)$ & $(-2.84)$ & $(-2.42)$ & $(-2.87)$ & $(-0.97)$ & $(-1.00)$ \\
\hline \multirow[t]{2}{*}{$L O G P B$} & $-0.0082 * * *$ & $-0.0079 * * *$ & $-0.0081 * * *$ & $-0.0079 * * *$ & $-0.0076 * * *$ & $-0.0075 * * *$ \\
\hline & $(-10.79)$ & $(-10.77)$ & $(-10.81)$ & $(-10.79)$ & $(-6.92)$ & $(-6.80)$ \\
\hline \multirow[t]{2}{*}{$I N D$} & 0.0010 & 0.0011 & 0.0010 & 0.0011 & -0.0011 & -0.0011 \\
\hline & $(1.36)$ & $(1.42)$ & $(1.37)$ & $(1.42)$ & $(-1.24)$ & $(-1.26)$ \\
\hline \multirow[t]{2}{*}{$L O G G D P$} & & & & & 0.0235 & 0.1168 \\
\hline & & & & & $(1.05)$ & $(1.50)$ \\
\hline \multirow[t]{2}{*}{ SPREAD } & & & & & -0.1621 & -1.2663 \\
\hline & & & & & $(-0.32)$ & $(-1.16)$ \\
\hline \multirow[t]{2}{*}{$I N F L$} & & & & & -1.8653 & $-1.4673 * * *$ \\
\hline & & & & & $(-1.45)$ & $(-2.31)$ \\
\hline \multirow[t]{2}{*}{ OPEN } & & & & & -0.0034 & $-0.2164 * *$ \\
\hline & & & & & $(-0.51)$ & $(-1.97)$ \\
\hline \multirow[t]{2}{*}{$L A W$} & & & & & $-0.0062 *$ & 0.0092 \\
\hline & & & & & $(-1.7)$ & $(0.77)$ \\
\hline \multirow[t]{2}{*}{$I D V$} & & & & & -0.0002 & $-0.0024 * *$ \\
\hline & & & & & $(-0.96)$ & $(-2.16)$ \\
\hline \multirow[t]{2}{*}{$U A I$} & & & & & 0.0001 & $-0.0011 *$ \\
\hline & & & & & $(0.43)$ & $(-1.82)$ \\
\hline \multirow[t]{2}{*}{ Constant } & $0.0206 * * *$ & $0.0178 * * *$ & $0.0207 * * *$ & $0.0182 * * *$ & 0.0143 & -0.0540 \\
\hline & $(7.26)$ & $(4.64)$ & $(7.3)$ & $(4.75)$ & $(0.23)$ & $(-0.40)$ \\
\hline $\begin{array}{l}\text { Country } \\
\text { dummies }\end{array}$ & no & yes & no & yes & no & yes \\
\hline $\mathrm{R}^{2}$ & 0.087 & 0.085 & 0.089 & 0.085 & 0.077 & 0.085 \\
\hline
\end{tabular}

Notes: Dependent variable is the return of each individual stock in excess of the risk-free rate. The estimation period in equation (3) (step one of Fama-MacBeth procedure) is different for each stock, and then all monthly coefficients are averaged over the sample period. In columns (1)-(4), the sample period is 1981-2006. In columns (5) and (6), due to the availability of macroeconomic data, the sample period is reduced to 1995-2006. T-statistics are in parentheses. $* * *, * *, *$ denotes $1 \%, 5 \%$ and $10 \%$ significance respectively. 
Second, companies located in Protestant countries perform the same, on average, as companies in Catholic countries. This finding is consistent with our argument that religion does not impact the performance of all companies. In columns (3) and (4) we introduce the interaction term to account for the combined effect of DSIN and DREL. Although all other coefficients are roughly the same, the interaction coefficient $b_{2}$ is positive (about $8 \%$ annually) and significant at the $1 \%$ level in model (4). After controlling for country-level characteristics, this coefficient is still significant at the 5\% level as shown in columns (5) and (6). This implies that religion affects only sin stock returns, or that sin stocks outperform other stocks only in Protestant countries. This result is consistent with our expectation and strongly supports our hypotheses, i.e., sin stocks earn a risk-adjusted premium in Protestant countries but not in Catholic countries.

\subsection{Robustness}

To assess the robustness of our empirical findings and to overcome the small sample issue (i.e., 66 sin stocks, of which 19 are listed in Protestant countries) we run the analysis including Germany as a Protestant country, consistent with Stulz and Williamson (2003). Germany gathers as much as 26 sin stocks (mostly brewing companies) and thus our sample of sin stocks significantly increases and the balance between Catholic and Protestant countries is evened out. New results for the cross-sectional analysis are presented in Table 5. The only difference with Table 4 is that now we have 4,415 stocks from 13 European countries. Results are similar to the ones presented in Table 4. In models (3)-(6), DSIN and DREL are individually not significant, whereas the interaction term $D S I N * D R E L$ is positive and significant. Its statistical significance has even increased to $1 \%$ level when including country-level characteristics.

We perform additional robustness checks by examining other risks that could be priced in the market and explain the sin stock premium. We address here why such risks (litigation risk, liquidity risk and information risk) cannot explain our findings. First, litigation risk has been found to significantly depress share prices, especially in the case of tobacco manufacturers (Hong and Kacperczyk, 2009). However tobacco litigation in Europe is much more recent and less developed than in the US (Daynard, 2001). Moreover, Grullon et al. (2010) show that firms located in a Protestant environment are less likely to face litigation. Second, our results cannot be explained by liquidity risk as listed tobacco manufacturers and alcohol producers are usually large companies (with smaller ones not being publicly traded). We collected data on volume turnover for sin companies and other companies with similar characteristics and actually found that sin stocks are, on average, more liquid than other comparable stocks. 
Table 5

Cross-sectional estimates of equation (4) using Fama-MacBeth procedure (including Germany).

\begin{tabular}{|c|c|c|c|c|c|c|}
\hline & (1) & $(2)$ & (3) & (4) & $(5)$ & (6) \\
\hline \multirow[t]{2}{*}{$D S I N$} & 0.0005 & $0.0021 *$ & -0.0025 & -0.0018 & -0.0009 & -0.0005 \\
\hline & $(0.39)$ & (1.84) & $(-1.25)$ & $(-0.96)$ & $(-0.44)$ & $(-0.23)$ \\
\hline \multirow[t]{2}{*}{ DREL } & -0.0008 & -0.0024 & -0.0009 & -0.0028 & -0.0084 & -0.1456 \\
\hline & $(-0.41)$ & $(-0.78)$ & $(-0.48)$ & $(-0.90)$ & $(-1.77)$ & $(-1.34)$ \\
\hline \multirow{2}{*}{$D S I N * D R E L$} & & & $0.0050 * *$ & $0.0067 * * *$ & $0.0061 * * *$ & $0.0063 * * *$ \\
\hline & & & $(2.06)$ & $(3.05)$ & $(2.37)$ & $(2.42)$ \\
\hline \multirow[t]{2}{*}{$\beta$} & $0.0040 *$ & $0.0035 *$ & $0.0041 *$ & $0.0035 *$ & 0.0012 & 0.0008 \\
\hline & (1.9) & $(1.70)$ & $(1.92)$ & $(1.70)$ & $(0.4)$ & $(0.27)$ \\
\hline \multirow[t]{2}{*}{$R E T$} & $-0.0356 * * *$ & $-0.0445 * * *$ & $-0.0356 * * *$ & $-0.0445 * * *$ & $-0.0418 * * *$ & $-0.0424 * * *$ \\
\hline & $(-6.48)$ & $(-9.23)$ & $(-6.49)$ & $(-9.24)$ & $(-6.15)$ & $(-6.33)$ \\
\hline \multirow[t]{2}{*}{$L O G M V$} & $-0.0008 * *$ & $-0.0009 * * *$ & $-0.0008 * *$ & $-0.0009 * * *$ & -0.0003 & -0.0003 \\
\hline & $(-2.19)$ & $(-2.45)$ & $(-2.21)$ & $(-2.46)$ & $(-0.55)$ & $(-0.58)$ \\
\hline \multirow[t]{2}{*}{$\angle O G P B$} & $-0.0079 * * *$ & $-0.0074 * * *$ & $-0.0079 * * *$ & $-0.0074 * * *$ & $-0.0062 * * *$ & $-0.0060 * * *$ \\
\hline & $(-11.04)$ & $(-10.92)$ & $(-11.02)$ & $(-10.92)$ & $(-6.35)$ & $(-6.10)$ \\
\hline \multirow[t]{2}{*}{$I N D$} & 0.0010 & 0.0008 & 0.0010 & 0.0008 & -0.0009 & -0.0009 \\
\hline & $(1.46)$ & $(1.18)$ & $(1.47)$ & (1.19) & $(-1.07)$ & $(-1.09)$ \\
\hline \multirow[t]{2}{*}{$L O G G D P$} & & & & & 0.0069 & $0.2166^{*}$ \\
\hline & & & & & $(0.38)$ & $(1.69)$ \\
\hline \multirow[t]{2}{*}{ SPREAD } & & & & & -0.4880 & -0.2157 \\
\hline & & & & & $(-1.45)$ & $(-0.22)$ \\
\hline \multirow[t]{2}{*}{ INFL } & & & & & -0.2952 & -0.6696 \\
\hline & & & & & $(-0.38)$ & $(-1.43)$ \\
\hline \multirow[t]{2}{*}{ OPEN } & & & & & $-0.0089 *$ & -1.0728 \\
\hline & & & & & $(-1.64)$ & $(-1.21)$ \\
\hline \multirow[t]{2}{*}{$L A W$} & & & & & -0.0004 & 0.0851 \\
\hline & & & & & $(-0.13)$ & $(0.97)$ \\
\hline \multirow[t]{2}{*}{$I D V$} & & & & & -0.0002 & -0.0070 \\
\hline & & & & & $(-1.01)$ & $(-1.56)$ \\
\hline \multirow[t]{2}{*}{$U A I$} & & & & & -0.0001 & -0.0055 \\
\hline & & & & & $(-0.95)$ & $(-1.59)$ \\
\hline \multirow[t]{2}{*}{ Constant } & $0.0196 * * *$ & $0.0173 * * *$ & $0.0197 * * *$ & $0.0175 * * *$ & 0.0300 & 0.0470 \\
\hline & $(7.33)$ & $(4.64)$ & $(7.36)$ & $(4.72)$ & $(0.6)$ & $(0.32)$ \\
\hline $\begin{array}{l}\text { Country } \\
\text { dummies }\end{array}$ & no & yes & no & yes & no & yes \\
\hline $\mathrm{R}^{2}$ & 0.075 & 0.082 & 0.075 & 0.082 & 0.074 & 0.081 \\
\hline
\end{tabular}

Notes: Dependent variable is the return of each individual stock in excess of the risk-free rate. The estimation period in equation (3) (step one of Fama-MacBeth procedure) is different for each stock, and then all monthly coefficients are averaged over the sample period. In columns (1)-(4), the sample period is 1981-2006. In columns (5) and (6), due to the availability of macroeconomic data, the sample period is reduced to 1995-2006. T-statistics are in parentheses. $* * *, * *, *$ denotes $1 \%, 5 \%$ and $10 \%$ significance respectively. 
Third, we collect data on analyst coverage in order to rule out any information risk. The average number of estimates for sin stocks and other comparable stocks is nearly identical (7.62 and 6.63 respectively) as is the standard deviation ( 7.60 and 7.05 respectively). These figures suggest that sin stocks' analyst coverage is no different than other stocks, i.e., the sin stock premium cannot be explained by a lack of information.

To summarize, we find that sin stocks in Protestant countries earn a positive risk premium over and above all other stocks, even above sin stocks in Catholic countries. This abnormal return is both economically and statistically significant across different measures of risk-adjusted performance and cannot be explained by litigation risk, liquidity risk or information risk. Our results are consistent with the idea that the values and norms of the dominant religion influence investor decisions at the country level and thus significantly impact expected returns of sin stocks.

\section{Conclusion and discussion}

Using a sample of 12 European countries (either primarily Catholic or Protestant), we provide evidence that aggregated religious preferences significantly impact the share price of sin companies (tobacco manufacturers and alcohol producers). Drawing on social identity and social impact theory, we argue that individuals exhibit higher sin aversion when located in Protestant countries (relative to Catholic countries). This implies that sin stocks are on average undervalued in Protestant countries as investors deliberately neglect these stocks in their investment decision. In other words, the share price of sin companies located in Protestant countries is depressed because of investors shunning these stocks, consistent with the social norm hypothesis in US literature. Our results show that investors in Protestant countries require a higher premium in order to invest in sin companies. In the cross-sectional analysis, after controlling for firm-specific, industry-specific and country-specific characteristics, sin stocks in Protestant countries outperform other stocks by $8.5 \%$ a year. Consistent with our hypothesis, we do not find any sin stock premium in Catholic countries. Finally, these results are robust to other potential sources of risk.

Our paper is the first to emphasize the existence of a sin stock premium in European markets and the role of religious preferences in social norms at the country level. Our findings are consistent with a segmented market model where a large proportion of investors located in Protestant countries choose to avoid sin stocks because of tastes for assets as consumption goods, implying market inefficiency through limits to arbitrage (Fama and French, 2007; 
Merton, 1987). We thus contribute to the literature on the sin stock premium by showing that religion is an important determinant of social norms as an explanation for sin stock abnormal returns. As such, our paper also links to the literature investigating the economic and financial impact of religion. Since the introduction of ethics into investment decisions, researchers have tried to understand the factors that drive socially responsible investors. Some of them have focused on religious preferences (Naber, 2001; Williams and Zinkin, 2005), and we provide evidence that religion continues to play a significant role. The results in this paper have to be interpreted with some caution. We realize that our findings rely on a small number of firms listed unevenly across European countries. Our sample of sin stocks is limited for two main reasons: many sin companies are privately held, and we followed a conservative approach in our selection of sin industries (including only alcohol and tobacco) and European countries (including only countries with a clear dominant religious denomination). We partly address this issue by including Germany in our robustness tests.

Overall, our paper provides unique evidence in support of the social norm hypothesis as an explanation for the sin stock premium. Our results suggest that the sin stock premium found on US stock markets is mainly driven by the social impact of Protestant attitudes towards sin and that there is no such premium in Catholic countries. Our findings have implications for both the sin stock premium and the socially responsible investment literature, and can potentially be extended to other stocks that will be neglected by investors because of religious preferences at the aggregate level. 


\section{A. Appendix: Data cleaning and portfolio construction}

We collect monthly financial data from December 1980 to December 2006 from Thomson DataStream. The total sample of companies consists of all non-financial common stocks traded in one of our 12 European countries, including all firms that ceased trading. Dead stocks are defined as stocks that merged, defaulted or were delisted. Thus, the data is relatively free of survivorship bias. We remove from the sample all companies with missing data for the return index or industrial sector. Moreover, the methodology of Ince and Porter (2006) is used in order to screen Thomson DataStream data and keep only relevant stocks. For instance, one has to screen the variables TYPE, NAME, and GEOG to identify and delete non-common stocks and non-local firms. In order to mitigate any currency effects, the analysis is based on euro returns. When constructing global portfolios (across different countries), we use the one-month Euro interest rate (from $1^{\text {st }}$ January 1999$)$ to proxy for the global risk-free rate $\left(R_{f}^{g}\right)$. Before this date, we compute portfolio returns in excess of the one-month French interest rate. ${ }^{1}$ In the crosssectional analysis on individual stocks, we use national short-term interest rates $\left(R_{f}^{n}\right)$. All interest rates are from OECD Statistics (originally provided by national central banks). After cleaning the dataset, there is a total number of 3,614 stocks across 12 countries over 312 months.

For the time-series analysis, we use a European version of the four-factor model and calculate the value-weighted return on global portfolios which are the market, SMB, HML and MOM portfolios. We first calculate monthly returns for a global market portfolio $\left(R_{m}^{g}\right)$ including all stocks in the sample for which data on return and market value are available for at least twelve months. Following Fama and French (1993), the SMB and HML portfolios include all stocks for which we have data on market value at the end of June $t$ and price-to-book ratio at the end of December $t-1$. The MOM portfolio return is the difference between the Top30 winner portfolio return and the Bottom30 loser portfolio return, using the past 12-month returns. For the cross-sectional analysis, we compute 12 national market portfolios $\left(R_{m}^{n}\right)$ from the same sample. All portfolios are value-weighted every month and expressed in terms of euro monthly returns. Table A.1 below reports the average return, the standard error, the median return, the minimum and the maximum returns over the period 1981-2006 for each national market portfolio and the global market portfolio. All stocks in our sample are not present at the same time in our portfolios and the last column of Table A.1 reports the number of stocks in each

\footnotetext{
${ }^{1}$ We test the robustness of the results to several European interest rates and the conclusions remain unchanged.
} 
portfolio as of 31/12/2005. The United Kingdom and France are the largest European markets, both in terms of number of listed companies and total market capitalization. The distribution of stocks between Catholic and Protestant countries is rather even, with $42 \%$ of all companies being listed in Catholic countries, the other $58 \%$ being quoted in Protestant countries.

\section{Table A.1}

Return statistics for national and global market portfolios (monthly percentages).

\begin{tabular}{|c|c|c|c|c|c|c|}
\hline & Mean & Std dev & Median & Min & Max & \# firms \\
\hline \multicolumn{7}{|l|}{ National market portfolios } \\
\hline Austria (1994-2006) & $0.62 \%$ & $5.58 \%$ & $0.20 \%$ & $-21.9 \%$ & $37.0 \%$ & 59 \\
\hline Belgium (1988-2006) & $1.10 \%$ & $4.77 \%$ & $1.06 \%$ & $-25.0 \%$ & $26.4 \%$ & 100 \\
\hline Denmark (1991-2006) & $1.26 \%$ & $5.46 \%$ & $1.32 \%$ & $-14.3 \%$ & $24.8 \%$ & 71 \\
\hline Finland (1995-2006) & $1.49 \%$ & $9.49 \%$ & $1.31 \%$ & $-29.3 \%$ & $31.1 \%$ & 111 \\
\hline France (1981-2006) & $1.26 \%$ & $6.08 \%$ & $1.51 \%$ & $-22.1 \%$ & $25.3 \%$ & 681 \\
\hline Rep. Ireland (1997-2006) & $1.30 \%$ & $6.71 \%$ & $1.34 \%$ & $-29.5 \%$ & $35.0 \%$ & 46 \\
\hline Italy (1988-2006) & $1.23 \%$ & $7.53 \%$ & $1.00 \%$ & $-19.9 \%$ & $29.7 \%$ & 195 \\
\hline Poland (1999-2006) & $1.47 \%$ & $10.63 \%$ & $1.40 \%$ & $-31.8 \%$ & $36.4 \%$ & 208 \\
\hline Portugal (1995-2006) & $0.84 \%$ & $6.70 \%$ & $0.63 \%$ & $-18.5 \%$ & $29.4 \%$ & 50 \\
\hline Spain (1990-2006) & $1.39 \%$ & $6.08 \%$ & $1.61 \%$ & $-28.9 \%$ & $19.2 \%$ & 92 \\
\hline Sweden (1990-2006) & $1.30 \%$ & $6.86 \%$ & $1.12 \%$ & $-20.8 \%$ & $24.1 \%$ & 313 \\
\hline UK (1981-2006) & $1.26 \%$ & $6.01 \%$ & $1.75 \%$ & $-25.5 \%$ & $53.6 \%$ & 1,480 \\
\hline \multicolumn{7}{|l|}{ Global market portfolio } \\
\hline Global (1981-2006) & $1.29 \%$ & $4.48 \%$ & $2.03 \%$ & $-23.6 \%$ & $12.9 \%$ & 3,406 \\
\hline
\end{tabular}

Notes: \# firms represents the number of stocks in each portfolio as of 31/12/2005. 


\section{References}

Arruñada, B., 2010. Protestants and Catholics: Similar Work Ethic, Different Social Ethic. The Economic Journal 120, 890-918.

Bianconi, M., Tan, L., 2010. Cross-listing Premium in the US and the UK Destination. International Review of Economics \& Finance 19, 244-259.

Cao, H.H., Han, B., Hirshleifer, D., Zhang, H.H., 2011. Fear of the Unknown: Familiarity and Economic Decisions. Review of Finance 15, 173-206.

Coates, D., Heckelman, J.C., Wilson, B., 2010. The political economy of investment: Sclerotic effects from interest groups. European Journal of Political Economy 26, 208-221.

Cortez, M.C., Silva, F., Areal, N., 2009. The performance of European socially responsible funds. Journal of business ethics 87, 573-588.

Daynard, R.A., 2001. Tobacco litigation: a mid-course review. Cancer Causes and Control 12, 383-386.

Döpke, J., Pierdzioch, C., 2006. Politics and the stock market: Evidence from Germany. European Journal of Political Economy 22, 925-943.

Eurosif, 2008. European SRI Study, in: Forum, E.S.a.R.I. (Ed.). Oxford University Press.

Eurosif, 2010. European SRI Study, in: Forum, E.S.a.R.I. (Ed.). Oxford University Press.

Fagan, D., Butler, S., 2011. 'What are we about?'An organizational study of the Pioneer Total Abstinence Association in present-day Ireland. Drugs: education, prevention and policy 18, 261-269.

Fama, E., MacBeth, J., 1973. Risk, return, and equilibrium: Empirical tests. The Journal of Political Economy 81, 607-636.

Fama, E.F., French, K.R., 1993. Common Risk Factors in the Returns on Stocks and Bonds. Journal of Financial Economics 33, 3-56.

Fama, E.F., French, K.R., 2007. Disagreement, Tastes, and Asset Prices. Journal of Financial Economics 83, 667-689.

Faruqee, H., Li, S., Yan, I.K., 2004. The Determinants of International Portfolio Holdings and Home Bias, Working Paper. IMF.

Feld, L.P., Voigt, S., 2003. Economic growth and judicial independence: cross-country evidence using a new set of indicators. European Journal of Political Economy 19, 497-527.

Grinblatt, M., Keloharju, M., 2001. How distance, language, and culture influence stockholdings and trades. The Journal of Finance 56, 1053-1073.

Grullon, G., Kanatas, G., Weston, J.P., 2010. Religion and corporate (mis) behavior, SSRN Working Paper.

Helble, M., 2007. Is God Good for Trade? Kyklos 60, 385-413.

Hilary, G., Hui, K.W., 2009. Does Religion Matter in Corporate Decision Making in America? Journal of Financial Economics 93, 455-473.

Hofstede, G., 1980. Culture's consequences, international differences in work-related values. Sage Publications, Inc.

Hogg, M.A., Abrams, D., 1988. Social identifications: A social psychology of intergroup relations and group processes. Psychology Press, London.

Hong, H., Kacperczyk, M., 2009. The price of sin: The effects of social norms on markets. Journal of Financial Economics 93, 15-36.

Hood, M., Nofsinger, J.R., Varma, A., in press. Conservation, Discrimination, and Salvation: Investors' Social Concerns in the Stock Market. Journal of Financial Services Research.

Hudson, R., 2005. Ethical investing: Ethical investors and managers. Business Ethics Quarterly 15, 641657.

Ince, O.S., Porter, R.B., 2006. Individual Equity Return Data from Thomson DataStream: Handle with Care. The Journal of Financial Research 29, 463-479. 
Jegadeesh, N., Titman, S., 1995. Overreaction, delayed reaction, and contrarian profits. Review of Financial Studies 8, 973-993.

Johnson, C.M., Meier, K.J., 1990. The Wages of Sin: Taxing America's Legal Vices. The Western Political Quarterly 43, 577-595.

Kim, I., Venkatachalam, M., 2011. Are Sin Stocks Paying the Price for Accounting Sins? Journal of Accounting, Auditing \& Finance 26, 415.

King, M.R., Segal, D., 2008. Market segmentation and equity valuation: Comparing Canada and the United States. Journal of International Financial Markets, Institutions and Money 18, 245-258.

Kumar, A., Page, J., 2011. Deviations From Norms and Informed Trading. Journal of Financial and Quantitative Analysis forthcoming.

Kumar, A., Page, J.K., Spalt, O.G., 2011. Religious beliefs, gambling attitudes, and financial market outcomes. Journal of Financial Economics 102, 671-708.

La Porta, R., Lopez-de-Silanes, F., Shleifer, A., Vishny, R., 1997. Legal Determinants of External Finance. Journal of Finance 52, 1131-1150.

Levine, H.G., 1992. Temperance cultures: Concern about Alcohol Problems in Nordic and Englishspeaking Cultures, in: Lader, M., Edwards, G., Drummon, D.C. (Eds.), The Nature of Alcohol and Drug-Related Problems. Oxford University Press, New York, pp. pp. 16-36.

Markowitz, H., 1952. Portfolio Selection. Journal of Finance 7, 77-91.

McCleary, R.M., Barro, R.J., 2006. Religion and Political Economy in an International Panel. Journal for the Scientific Study of Religion 45, 149-175.

Merton, R.C., 1987. A Simple Model of Capital Market Equilibrium with Incomplete Information. Journal of Finance 42, 483-510.

Naber, M., 2001. Catholic Investing: The Effects of Screens on Financial Returns (Digest Summary). Journal of Investing 10, 58-65.

Renneboog, L., Spaenjers, C., 2012. Religion, economic attitudes, and household finance. Oxford Economic Papers 64, 103-127.

Satterthwaite, S., 2005. Faster horses, older whiskey, and more money: An analysis of religious influence on referenda voting. Journal for the scientific study of religion 44, 105-112.

Sharpe, W.F., 1964. Capital Asset Prices: A Theory of Market Equilibrium under Conditions of Risk. Journal of Finance 19, 425-442.

Sharpe, W.F., 1966. Mutual fund performance. The Journal of Business 39, 119-138.

Smith, I., Sawkins, J.W., Seaman, P.T., 1998. The Economics of Religious Participation: A Crosscountry Study. Kyklos 51, 25-44.

Statman, M., Glushkov, D., 2009. The Wages of Social Responsibility. Financial Analysts Journal 65, 33-46.

Stulz, R.M., Williamson, R., 2003. Culture, Openness, and Finance. Journal of Financial Economics 70, 313-349.

Tesar, L.L., Werner, I.M., 1995. Home Bias and High Turnover. Journal of International Money and Finance 14, 467-492.

Weber, M., 1905. The Protestant ethic and the spirit of capitalism. Routledge, London.

WHO, 1999. Meeting on Tobacco and Religion, Tobacco Free Initiative. World Health Organization, Geneva, Switzerland.

WHO, 2004. Global Status Report: Alcohol Policy. World Health Organization.

Williams, G., Zinkin, J., 2005. Can Corporate Social Responsibility Be a Bridge Between Civilisations? mimeo, Nottingham University Business School-Malaysia Campus. 